\title{
Article \\ Soil Bacteria as Potential Biological Control Agents of Fusarium Species Associated with Asparagus Decline Syndrome
}

\author{
Eduardo De la Lastra, María Camacho * and Nieves Capote *(i) \\ Andalusian Institute of Agricultural and Fisheries Research and Training (IFAPA), Center "Las Torres", \\ 41200 Seville, Spain; eduardo.lastra@juntadeandalucia.es \\ * Correspondence: mariag.camachomartinez@juntadeandalucia.es (M.C.); marian.capote@juntadeandalucia.es (N.C.)
}

Featured Application: The Bacillus strains FC37 and Hvs2 could be used as potential biocontrol agents as a sustainable and environmentally friendly control strategy for asparagus fields affected by the decline syndrome.

check for updates

Citation: De la Lastra, E.; Camacho, M.; Capote, N. Soil Bacteria as Potential Biological Control Agents of Fusarium Species Associated with Asparagus Decline Syndrome. Appl. Sci. 2021, 11, 8356. https://doi.org/10.3390/ app11188356

Academic Editors: Raúl Rivas-González, José David Flores-Félix and Esther Menéndez

Received: 19 July 2021

Accepted: 7 September 2021

Published: 9 September 2021

Publisher's Note: MDPI stays neutral with regard to jurisdictional claims in published maps and institutional affiliations.

Copyright: (c) 2021 by the authors. Licensee MDPI, Basel, Switzerland. This article is an open access article distributed under the terms and conditions of the Creative Commons Attribution (CC BY) license (https:// creativecommons.org/licenses/by/ $4.0 /)$.
Abstract: To avoid the use of agrochemicals in agriculture, alternative methods are emerging to control plant pathogens. Some plant growth-promoting rhizobacteria (PGPR) can be used as biocontrol agents since they can induce protection against pathogens. The aim of this study was to evaluate the protective effect of several PGPR strains against the main Fusarium species involved in asparagus decline syndrome (ADS): F. proliferatum, F. oxysporum f. sp. asparagi and F. redolens. In vitro antagonism assays showed that all the bacteria inhibited the mycelium growth of the three Fusarium species. The most effective strains (Streptomyces fradiae Hvs6, Bacillus paralicheniformis Hvs2 and Bacillus velezensis FC37) were tested to evaluate their protective effect on asparagus plants inoculated with pathogenic Fusarium isolates. Strains FC37 and Hvs2 were the most effective in controlling pathogenic F. proliferatum and F. oxysporum f. sp. asparagi, but neither could protect against $F$. redolens isolates. The production of hydrolytic enzymes such as $\beta$-glucosidase, amylase and protease by these bacterial strains could be involved in the structural degradation of the fungal cell wall. In addition, the production of toxic volatile compounds, such as hydrogen cyanide, may inhibit the fungal growth, and the production of phosphate solubilizers could be related to the plant growth promotion. These results suggest that strains FC37 and Hvs2 could be used as potential biocontrol agents as a sustainable and environmentally friendly control strategy for ADS-affected fields.

Keywords: Fusarium proliferatum; F. oxysporum; enzymatic activity; Bacillus paralicheniformis; Bacillus velezensis; biocontrol; PGPR; hydrogen cyanide; phosphate solubilization

\section{Introduction}

Asparagus (Asparagus officinalis L.) is a highly important crop worldwide. The crop has a great increase due to the demand of consumers for healthy foods. Spears have a high nutritional value and functional properties, providing dietary fiber and high content of natural antioxidants and other bioactive components, such as phenolic acids, flavonoids and ascorbic acid [1,2].

Asparagus decline syndrome (ADS) is one of the most important diseases of asparagus in most producing areas [3]. Symptoms consist of root rot of seedlings and mature plants that led to a drastic decrease in feeder roots and loss of their cortical parenchyma. The crowns present discoloration that evolves to necrosis, which extends to the base of spears. The adult plant shows progressive chlorosis, a wilting of fronds that resembles drought symptoms, and finally dies. Fields crops with previous ADS symptoms also display replanting problems, which imply premature uprooting of plants and prevents affected fields from being planted with asparagus. Several factors have been suggested to be involved in ADS, including abiotic factors, such as the accumulation in the soil of allelopathic compounds produced by the asparagus plant [4,5], the accumulation of herbicide 
residues, nutrient starving or the alteration of the soil structure. Among biotic factors, ADS has been closely associated with the presence of pathogenic species of Fusarium in the soil. Fusarium proliferatum, F. oxysporum f. sp. asparagi and F. redolens were the main Fusarium species associated with ADS in Spain [6,7].

The control of ADS is challenging because the causal agents can survive for long time in the soil and plant debris and can be disseminated by nursery plant material and irrigation water [8,9]. In addition, the commercial varieties have demonstrated high susceptibility to Fusarium infection, and tolerant or resistant varieties are not currently available. Chemical soil disinfestation prior to planting is one of the most used control strategies for ADS. However, the drastic decrease in the use of chemical fungicides applied to agriculture, in accordance to the European strategy "Farm to fork", aimed to prevent fungicide resistance and to avoid damages to human health and the environment, which has prompted the search for more sustainable alternatives. Biological control has emerged as one of the most sustainable control strategies. Fungal-based biological control agents such as non-pathogenic strains of F. oxysporum [10,11], arbuscular mycorrhiza [12], Trichoderma harzianum [13], and endophytic [14] and rhizospheric [15] fungi have been used for achieving tolerance to Fusarium root rot of asparagus. Regarding bacteria, Streptomyces griseus could control Fusarium diseases of asparagus in vitro, via antibiotic production [16], and species of Pseudomonas and Serratia could suppress Fusarium crown and root rot of asparagus [17]. Another asparagus disease, such as Phytophthora rot of asparagus, could also be controlled by the use of rhizospheric bacteria [18].

In this sense, the use of bacterial strains isolated from the soil or the rhizosphere of healthy plants as biological control agents has allowed reducing the incidence and severity of multiple fungal plant diseases. The modes of action are variable and consist of the competition for nutrients, the production of antifungal compounds such as hydrolytic enzymes, or the release of toxic substances which provide a broad antagonistic activity against different soil-borne phytopathogenic fungi [19]. In addition, some rhizospheric bacteria are able to induce the plant growth by producing plant growth promoting compounds such as auxin phytohormone [20] or facilitating the uptake of certain nutrients from the environment, such as nitrogen, potassium or phosphorus [21], which may help the plant fight pathogens [22].

The objective of this work was to evaluate the ability of five rhizospheric bacterial strains of the species Bacillus amyloliquefaciens, B. paralicheniformis, B. velezensis, Brevibacterium frigoritolerans and Streptomyces fradiae in the control of the main Fusarium species associated with ADS (F. proliferatum, F. oxysporum f. sp. asparagi and F. redolens), through both in vitro and in planta assays, and to propose possible mechanisms of action of the bacterial strains by characterizing the antifungal metabolites and growth promoter compounds produced by the biocontrol strains.

\section{Materials and Methods}

\subsection{Fungal Isolates}

Fusarium proliferatum isolates Fp3 and Fp86, F. oxysporum isolates Fo14 and Fo125, and F. redolens isolates Fr7 and Fr104 were obtained from symptomatic asparagus plants collected from ADS-affected asparagus fields [6] and conserved at the IFAPA's fungal collection, Seville, Spain.

\subsection{Bacterial Strains}

Five bacterial strains were used to evaluate their potential as antagonists and biological control agents: Bacillus amyloliquefaciens Adb14, B. paralicheniformis Hvs2, B. velezensis FC37, Brevibacterium frigoritolerans Hvs8 and Streptomyces fradiae Hvs6. All of them belonged to the IFAPA's bacterial collection. Strains AdB14 and FC37 were, respectively, isolated from strawberry plants and the rhizosphere of strawberry plants collected in Moguer (Huelva). Strains Hvs2, Hvs6 and Hvs8 were originally isolated from the rhizosphere of Arthrocaulon plants growing at Lebrija marshes (Seville). The strains were identified by $16 \mathrm{~S}$ rDNA 
sequencing using universal primers 27F-5'-AGAGTTTGATCCTGGCTCAG- ${ }^{\prime}$ and $1492-$ R-5' GGTTACCTTGTTACGACTT- $3^{\prime}$, and subsequently analyzed using the BLAST tool and EzBioCloud database. Finally, accession numbers from OU487633 to OU487636 were assigned to the sequences for FC37, Hvs8, Hvs6 and AdB1, respectively, and OU570686 for Hvs2 (Supplementary Materials 1).

\subsection{Dual Plate Confrontation Experiments}

Bacterial suspensions were obtained by growing bacterial strains in nutrient broth (NB) liquid medium at $28^{\circ} \mathrm{C}$ with continuous shaking (160 rpm) for $24 \mathrm{~h}$. Bacterial cultures were then centrifuged at $10.000 \times g$ for $5 \mathrm{~min}$ and the pellet was resuspended in $0.03 \mathrm{M}$ magnesium sulfate buffer to get a suspension of $10^{9}$ bacteria $/ \mathrm{mL}$. Four droplets of each bacterial suspension $(10 \mu \mathrm{L})$ were loaded into the periphery of Petri dishes $(6 \mathrm{~cm})$ containing Potato dextrose agar (PDA) and incubated at $28^{\circ} \mathrm{C}$ for $24 \mathrm{~h}$. Plates without bacterial inoculum were used as negative controls. Then, a 5-day-old mycelial disc ( $5 \mathrm{~mm}$ diam.) from the edge of an actively growing colony of each fungal pathogen was placed at the center of the PDA plates and incubated at $25^{\circ} \mathrm{C}$. Three replicates per dual confrontation were used. Percentage of inhibition of the pathogen development respect to the control was assessed at 7 days after confrontation and it was calculated using the formula 1:

$$
\%=[(\mathrm{Rc}-\mathrm{Ri}) / \mathrm{Rc}] \times 100
$$

where $R_{c}$ is the radial growth of the fungal pathogen in the control plates (mm), and Ri is the radial growth of the fungal pathogen in the test plates $(\mathrm{mm})$.

\subsection{Growth Chamber Experiments}

Growth chamber experiments were performed to evaluate the control efficacy of the three bacterial strains that showed the highest percentage of fungal growth inhibition: S. fradiae Hvs6, B. velezensis FC37 and B. paralicheniformis Hvs2. Asparagus seeds cv. Grande F1 were surface disinfested by immersion with $10 \%$ sodium hypochlorite for $10 \mathrm{~min}$, subsequently rinsed with tap water and air dried on sterile paper in a laminar flow cabinet. Seeds were then immersed in a suspension of $10^{8}$ bacteria $/ \mathrm{mL}$ (prepared as explained above) and incubated at room temperature for $1 \mathrm{~h}$ with gentle agitation. Inoculated seeds were germinated on $1 \%$ agar-water Petri dishes at $25^{\circ} \mathrm{C}$ in the dark. Non-inoculated seeds were immersed in sterile NB liquid medium. Once the radicle had emerged by $1-1.5 \mathrm{~cm}$, seedlings were trespassed to incubation trays with sterile vermiculite and incubated in a growth chamber set at $25 / 18{ }^{\circ} \mathrm{C}$ (light/dark) with a $14 \mathrm{~h}$ photoperiod for 2 weeks. When plants reached an appropriate size, they were first inoculated by adding $1 \mathrm{~mL}$ of freshly prepared bacterial suspension $\left(10^{8}\right.$ bacteria $\left./ \mathrm{mL}\right)$ around each plant, and $24 \mathrm{~h}$ later by immersing the roots in a fungal suspension of $10^{6}$ conidia $/ \mathrm{mL}$ for $30 \mathrm{~min}$. For fungal inoculum preparation, fungal isolates were cultured in Czapek-Dox broth on a rotary shaker $(150 \mathrm{rpm})$ at $25{ }^{\circ} \mathrm{C}$ with a $12 \mathrm{~h}$ photoperiod for 10 days. The spore suspension was filtered through four layers of cheese cloth and adjusted with sterile distilled water to a concentration of $10^{6}$ conidia $/ \mathrm{mL}$. Non-inoculated control plants were root-dipped in sterile Czapek-Dox broth. Plants were then transplanted into pots with $1.6 \mathrm{~L}$ of sterile vermiculite and maintained in a growth chamber set at $25 / 18^{\circ} \mathrm{C}$ (light/dark) with a $14 \mathrm{~h}$ photoperiod (14,000 lux) for 60 days. Plants only inoculated with bacteria, only inoculated with fungi and non-inoculated plants were used as controls. Plants were watered as required and fertilized once a week with Hoagland medium [23]. Twelve plants were tested for each fungal-bacterial combination, with three plants per pot arranged in a completely randomized design.

\subsection{Disease Assessments}

Plants were evaluated weekly for disease severity based on a 1-5 scale, where $1=1-20 \%, 2=21-40 \%, 3=41-60 \%, 4=61-80 \%$ and $5=81-100 \%$ of the fronds showing chlorosis, necrosis or wilt [6]. The progression of the disease as area under the disease 
progress curve (AUDPC) was calculated weekly throughout 2 months for each species. At the end of each experiment, the percentage of dead plants was determined. Plants were removed from the pots, the roots rinsed in tap water and the severity of the symptoms on the root system was assessed on a 1-5 scale such as that described above for the aerial part. The fronds and root wet weights were measured. Data were expressed as mean \pm standard error of 12 replicate plants inoculated with each isolate. To confirm that the symptomatic and dead asparagus plants were affected by the inoculated Fusarium species, all dead plants and several randomly symptomatic plants per isolate were analyzed for recovery of the inoculated fungal isolate. Plants were taken out of the pots and roots, stems and fronds were surface sterilized independently in 1\% sodium hypochlorite for $2 \mathrm{~min}$, rinsed twice with sterile water and dried in a laminar flow chamber. Four small pieces from each plant tissue were cut and placed on PDA plates supplemented with $0.2 \%$ streptomycin. Plates were incubated at $25^{\circ} \mathrm{C}$ for seven days in a $12 \mathrm{~h}$ photoperiod. Fusarium species were identified by morphological characteristics $[24,25]$.

\subsection{Enzymatic Activity of Bacterial Strains}

All the isolates were tested for the following biocontrol activities: protease, chitinase, amylase and $\beta$-glucosidase, and for the presence of volatile compounds (hydrogen cyanide, $\mathrm{HCN})$. Protease, chitinase and amylase activities were recorded according to Mesa et al. (2015) [26], while $\beta$-glucosidase production was recorded following the method described by Gong et al. (2012) [27]. Briefly, for protease, chitinase and $\beta$-glucosidase activities, strains were grown in casein agar, minimal medium supplemented with colloidal chitin and Luria Bertani (LB) medium containing $0.1 \%$ esculin and $0.05 \%$ ferric ammonium citrate, respectively, and plates were incubated at $28{ }^{\circ} \mathrm{C}$ for 5 days until clearing (for protease and chitinase) or black (for $\beta$-glucosidase) zones could be seen around the colonies. For amylase activity, strains were inoculated on starch agar, incubated, and revealed by flooding the plates with lugol. The presence of volatile compounds was carried out joining the protocol of Bano and Musarrat (2003) [28], in which they used King medium supplemented with $0.44 \%$ glycine for growing the strains, and the protocol of Pacheco-Hernández et al. (2015) [29], in which a sterile filter paper saturated with a solution of picric acid were placed on the lid of the plate. Finally, the valuation of $\mathrm{HCN}$ production was done on a 0-3 scale according to Reetha et al. (2014) [30], where the initial yellow color (0) changed to dark brown (3).

\subsection{Production of Plant Growth-Promoting Compounds}

Bacteria were tested for their ability for auxin and siderophore production following the protocols of Benizri et al. (1998) [31] and Alexander and Zuberer (1991) [32], respectively. Briefly, for auxin production, bacteria were grown in NB medium supplemented with L-Try (100 $\mathrm{mg} \mathrm{L}^{-1}$ ) and IAA production was colorimetrically measured after adding Salkowski reagent ( $2 \% 0.5 \mathrm{FeCl}_{3}$ in $35 \% \mathrm{HCLO}_{4}$ solution), and siderophore production was detected by the presence of orange halos on chrome azurol S (CAS) plates. For phosphate solubilization, transparent halos were recorded after the bacteria were grown in NB plates containing $0.5 \%$ $\mathrm{K}_{2} \mathrm{HPO}_{4}$ and $1 \% \mathrm{CaCl}_{2}$, following the procedure described by de Freitas et al. (1997) [33].

\subsection{Data Analysis}

Analyses of variance were performed for the fungal growth inhibitions produced by the different bacteria strains in the dual plate confrontation assays. Arcsine square root transformation was applied to inhibition percentages. Means were compared by LSD's significant difference test $(p \leq 0.05)$.

Individual analysis of variance was performed (fronds and root weights) for each Fusarium isolate in the growth chamber experiments with plants. Means were compared by Tukey's whole significant difference test $(p \leq 0.05)$. Additional non-parametric KruskalWallis tests were performed when the assumption of the normality of the distributions was not sustainable (disease severity on fronds and roots, and AUDPC). All statisti- 
cal analyses were carried out using Statistix 9 package software (Analytical Software, Tallahassee, FL, USA).

\section{Results}

\subsection{Antagonism In Vitro}

The strain Hvs6 significantly showed the highest percentage of fungal growth inhibition (81-84\%) for all tested isolates of F. proliferatum, F. oxysporum $\mathrm{f}$. sp. asparagi and F. redolens. FC37 and Hvs2 inhibited up to 73 and $82 \%$ the growth of the fungal isolates assayed, respectively. The Adb14 strain reduced the mycelial growth from 41 to $50 \%$. Hsv8 showed the lowest ability for mycelial growth inhibition (10-20\%; Figures 1 and 2).

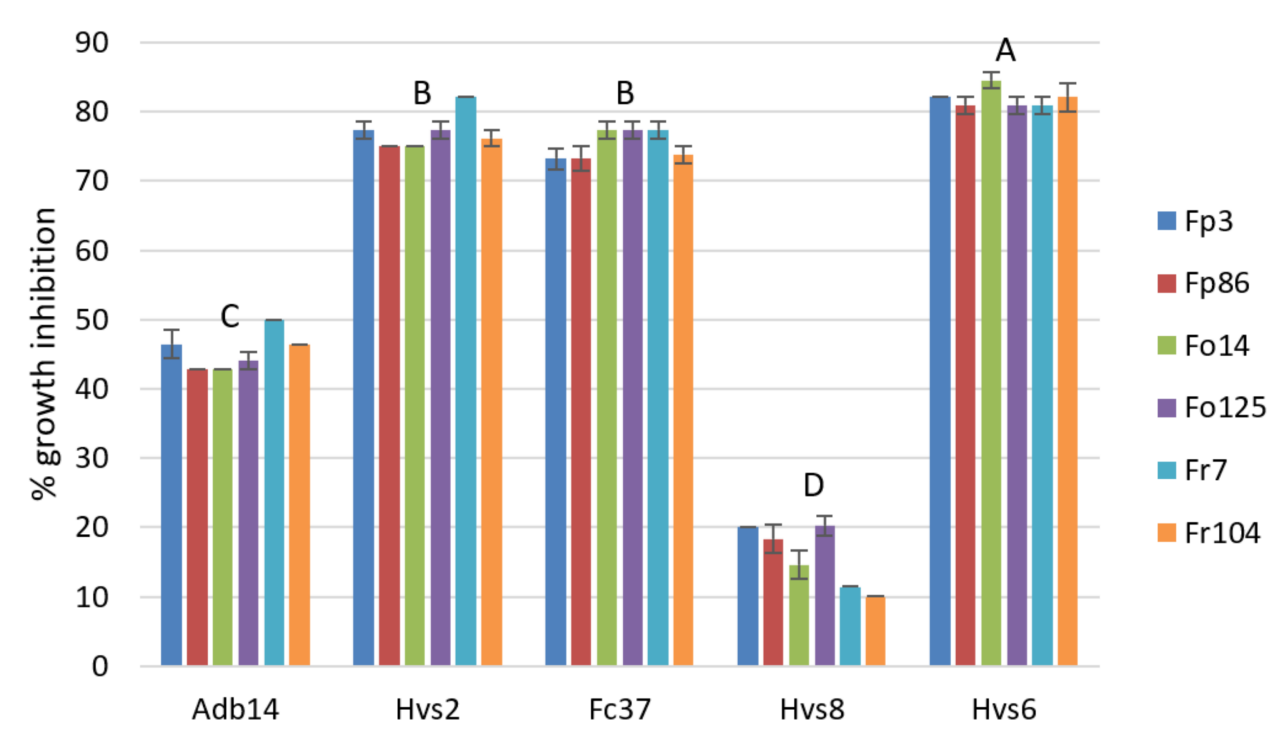

Figure 1. Percentage of mycelial growth inhibition of Fusarium proliferatum (Fp), F. oxysporum $\mathrm{f} s \mathrm{p}$. asparagi (Fo), and F. redolens (Fr) isolates by Bacillus amyloliquefaciens Adb14, B. paralicheniformis Hvs2, B. velezensis FC37, Brevibacterium frigoritolerans Hvs8, and Streptomyces fradiae Hvs6 bacterial strains. Results are the mean of three replicates and error bars correspond to the standard error calculated as the quotient of the standard deviation and the square root of the number of samples analyzed. Different letters indicate significant differences among bacterial strains based on the LSD test at $p \leq 0.05$. 


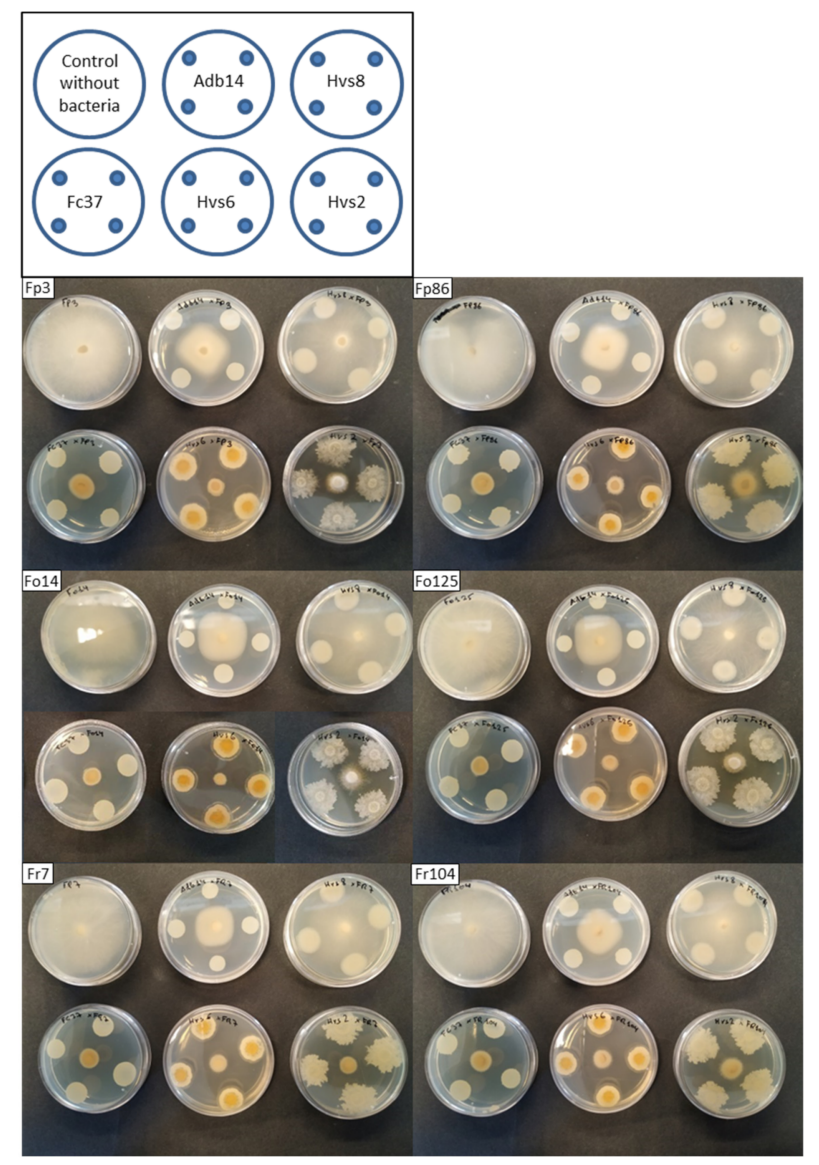

Figure 2. Dual confrontation experiments showing the inhibition of the fungal mycelial growth of Fusarium proliferatum (isolates Fp3 and Fp86), F. oxysporum f. sp. asparagi (isolates Fo14 and Fo125) and F. redolens (isolates Fr7 and Fr104) by the bacterial strains Adb14, Hvs8, FC37, Hvs6 and Hvs2.

\subsection{Biological Control of Fusarium Species in Growth Chamber Conditions}

Non-inoculated plants and plants inoculated only with the bacterial strains did not show disease symptoms throughout the experiment. Control plants inoculated with the strain FC37 showed higher root weights than plants inoculated with strains Hvs2 and Hvs6 or non-inoculated (Table 1).

The strain FC37 showed the highest level of biocontrol. Asparagus plants coinoculated with F. proliferatum isolates Fp3 and Fp86, respectively, and strain FC37 reduced the plant mortality by 58 and $63 \%$ with respect to the control inoculated only with the fungal isolates. In addition, the weight of shoots and roots were significantly higher, and the severity of shoot and root symptoms, and the AUDPC were lower in plants coinoculated with F. proliferatum isolates and FC37 than in those inoculated only with the fungal isolates (Table 1).

A similar behavior was observed in plants inoculated with isolates of $F$. oxysporum $\mathrm{f}$. sp. asparagi. The coinoculation of the fungal isolate Fo125 with the bacteria FC37 reduced the percentage of dead plants (24\%) and produced significant higher root and shoot weights compared with plants inoculated only with the fungal isolate. The severity of roots was similar, although the shoot severity and AUDPC were lower in the coinoculated plants. Fo14 isolate did not produce dead plants, although the coinoculation with bacteria FC37 produced a significant increase in the root biomass and a reduction in root symptoms and AUDPC. However, no benefits of strain FC37 were observed in plants inoculated with any of the isolates of $\mathrm{F}$. redolens, except for a slight increase in plant biomass observed in plants coinoculated with Fr104 and FC37, compared with those inoculated only with the fungus (data not shown). 
The strain Hvs2 showed an intermediate ability to control F. proliferatum and F. oxysporum $\mathrm{f}$. sp. asparagi isolates pathogenic to asparagus, reducing between 26 and $63 \%$ the percentage of dead plants, avoiding the loss of plant biomass, and reducing disease symptoms (except for isolate Fo125 of F. oxysporum f. sp. asparagi) in plants coinoculated with this bacteria and the respective Fusarium isolates (Table 1). No benefits of Hvs2 were observed in plants inoculated with any of the isolates of $F$. redolens.

The strain Hvs6 showed a lower ability to control F. proliferatum Fp3 and Fp86 isolates, reducing 14 and $51 \%$ the percentage of dead plants, respectively. In addition, the coinoculation of Hvs6 and Fp86 isolate avoided the loss of plant biomass and reduced the shoot and root disease symptoms, although to a lesser extent than FC37 and Hvs2 (Table 1). No beneficial effect of Hvs6 was observed on plants inoculated with F. oxysporum and F. redolens isolates.

Fungal isolates were reisolated from the roots of all inoculated plants although the percentage of fungal recovery was lower in plants coinoculated with any bacterial strain (data not shown).

Table 1. Percentage of dead plants, root and shoot fresh weight, symptoms severity and the area under the disease progress curve (AUDPC) for in planta assays of coinoculations of Fusarium proliferatum (isolates Fp3 and Fp86), and F. oxysporum $\mathrm{f}$. sp. asparagi (isolates Fo14 and Fo125) and the bacterial strains FC37, Hvs2, and Hvs6. Data are mean \pm standard deviation of 9-12 plants. For each fungal isolate, different letters indicate significant differences among treatments $(p \leq 0.05)$.

\begin{tabular}{ccccccc}
\hline $\begin{array}{c}\text { Fungus-Bacteria } \\
\text { Coinoculations }\end{array}$ & $\begin{array}{c}\text { Dead Plants } \\
\mathbf{( \% )}\end{array}$ & $\begin{array}{c}\text { Root Fresh } \\
\text { Weight (g) }\end{array}$ & $\begin{array}{c}\text { Shoot Fresh } \\
\text { Weight (g) }\end{array}$ & Root Severity & $\begin{array}{c}\text { Shoot } \\
\text { Severity }\end{array}$ & AUDPC \\
\hline FC37 & 0 & $0.92 \pm 0.43$ & $0.20 \pm 0.06$ & $0.1 \pm 0.3$ & $0.7 \pm 0.5$ & $0.3 \pm 0.4$ \\
Hvs2 & 0 & $0.79 \pm 0.23$ & $0.20 \pm 0.05$ & $0.1 \pm 0.3$ & $0.8 \pm 0.8$ & $0.2 \pm 0.3$ \\
Hvs6 & 0 & $0.77 \pm 0.22$ & $0.20 \pm 0.04$ & $0.0 \pm 0.0$ & $0.8 \pm 1.0$ & $0.3 \pm 0.5$ \\
Non-inoculated & 0 & $0.73 \pm 0.42$ & $0.21 \pm 0.08$ & $0.1 \pm 0.3$ & $0.2 \pm 0.4$ & $0.0 \pm 0.0$ \\
\hline Fp3-FC37 & 33 & $0.11 \pm 0.09 \mathrm{a}$ & $0.07 \pm 0.04 \mathrm{a}$ & $2.6 \pm 1.1$ & $3.3 \pm 1.5$ & $2.3 \pm 1.3$ \\
Fp3-Hvs2 & 58 & $0.08 \pm 0.05 \mathrm{ab}$ & $0.05 \pm 0.03 \mathrm{ab}$ & $2.6 \pm 0.9$ & $4.3 \pm 1.1$ & $2.9 \pm 1.1$ \\
Fp3-Hvs6 & 67 & $0.04 \pm 0.05 \mathrm{~b}$ & $0.02 \pm 0.02 \mathrm{~b}$ & $3.2 \pm 1.0$ & $3.9 \pm 1.9$ & $2.7 \pm 1.4$ \\
Fp3 & 78 & $0.04 \pm 0.04 \mathrm{~b}$ & $0.05 \pm 0.04 \mathrm{ab}$ & $2.9 \pm 0.6$ & $4.1 \pm 1.8$ & $3.3 \pm 1.4$ \\
\hline Fp86-FC37 & 33 & $0.20 \pm 0.19 \mathrm{a}$ & $0.08 \pm 0.05 \mathrm{a}$ & $2.6 \pm 0.9$ & $3.3 \pm 1.7$ & $1.7 \pm 1.0$ \\
Fp86-Hvs2 & 33 & $0.14 \pm 0.11 \mathrm{ab}$ & $0.08 \pm 0.05 \mathrm{a}$ & $2.6 \pm 0.8$ & $3.4 \pm 1.4$ & $2.0 \pm 1.1$ \\
Fp86 Hvs6 & 44 & $0.12 \pm 0.14 \mathrm{ab}$ & $0.07 \pm 0.06 \mathrm{a}$ & $3.0 \pm 1.2$ & $3.3 \pm 1.9$ & $2.3 \pm 1.8$ \\
Fp86 & 89 & $0.03 \pm 0.01 \mathrm{~b}$ & $0.02 \pm 0.01 \mathrm{~b}$ & $3.4 \pm 0.5$ & $4.7 \pm 1.1$ \\
\hline Fo125-FC37 & 25 & $0.26 \pm 0.10 \mathrm{a}$ & $0.11 \pm 0.05 \mathrm{a}$ & $2.2 \pm 1.0$ & $2.7 \pm 1.8$ & $3.2 \pm 0.8$ \\
Fo125-Hvs2 & 42 & $0.10 \pm 0.04 \mathrm{~b}$ & $0.07 \pm 0.04 \mathrm{ab}$ & $3.0 \pm 0.6$ & $3.3 \pm 1.7$ & $2.3 \pm 1.2$ \\
Fo125-Hvs6 & 67 & $0.06 \pm 0.08 \mathrm{~b}$ & $0.05 \pm 0.06 \mathrm{~b}$ & $3.3 \pm 1.1$ & $4.2 \pm 1.4$ & $2.7 \pm 1.0$ \\
Fo125 & 33 & $0.12 \pm 0.08 \mathrm{~b}$ & $0.06 \pm 0.03 \mathrm{~b}$ & $2.2 \pm 1.2$ & $2.8 \pm 1.9$ & $1.9 \pm 1.6$ \\
\hline Fo14 -FC37 & 0 & $0.79 \pm 0.21 \mathrm{a}$ & $0.19 \pm 0.05 \mathrm{a}$ & $0.5 \pm 0.5$ & $0.9 \pm 0.5$ & $0.2 \pm 0.2$ \\
Fo14-Hvs2 & 0 & $0.67 \pm 0.18 \mathrm{ab}$ & $0.16 \pm 0.04 \mathrm{a}$ & $0.7 \pm 0.5$ & $0.5 \pm 0.5$ & $0.3 \pm 0.4$ \\
Fo14-Hvs6 & 0 & $0.69 \pm 0.16 \mathrm{ab}$ & $0.18 \pm 0.04 \mathrm{a}$ & $0.8 \pm 0.4$ & $0.9 \pm 1.1$ & $0.4 \pm 0.7$ \\
Fo14 & 0 & $0.53 \pm 0.12 \mathrm{~b}$ & $0.15 \pm 0.05 \mathrm{a}$ & $0.7 \pm 0.5$ & $0.7 \pm 1.0$ & $0.3 \pm 0.4$ \\
\hline
\end{tabular}

\subsection{Biocontrol Enzymatic Activity of Bacterial Strains}

The biocontrol-related enzymatic activities measured in the bacterial strains are shown in Figure 3. Strain Hvs2 showed the highest diversity of enzymatic activities. All strains produced protease and amylase, although FC37 presented the highest level of both. On the other hand, chitinase activity was the least common activity, being shown only by strain Hvs2. Production of toxic volatile HCN was observed in Hsv2 and Hvs8 strains, being more remarkable in the former. 


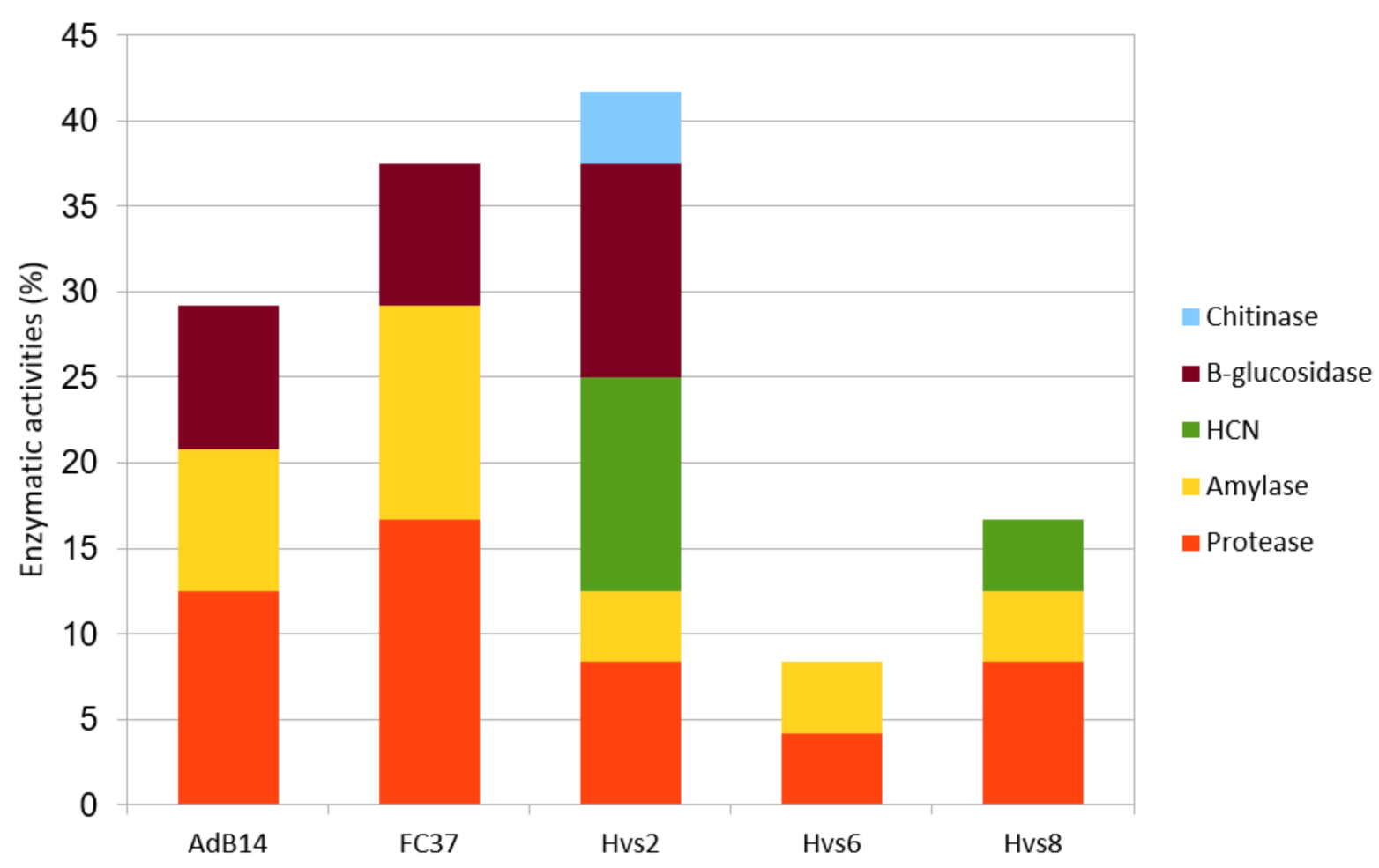

Figure 3. Percentage of biocontrol enzymatic activities displayed by strains Adb14, FC37, Hvs2, Hvs6, and Hvs8.

\subsection{Production of Plant Growth-Promoting Compounds}

Results obtained from plant growth promoting test are shown in Table 2. All the tested strains showed only one PGP property, exception made of strain Hvs2 which showed no properties at all. It is noticeable the high siderophores production showed by strain Hvs6.

Table 2. Plant growth promoting compounds produced by bacterial strains Adb14, FC37, Hvs2, Hvs6 and Hvs8.

\begin{tabular}{cccc}
\hline Bacterial Strain & Siderophore & Phosphate Solubilization & Auxin \\
\hline Adb14 & + & - & - \\
FC37 & - & + & - \\
Hvs2 & - & - & - \\
Hvs6 & +++ & - & - \\
Hvs8 & - & - & + \\
\hline
\end{tabular}

\section{Discussion}

Soil-borne fungal diseases cause worldwide economic losses in agriculture. Alternative control methods are desirable to avoid using chemical fungicides, which can potentially be harmful to the environment and human health. Numerous studies have been published about the ability of PGPR to control soil-borne fungal diseases in different crops [34-36], however there are few studies based on PGPR to control Fusarium species involved in ADS, as far as we know. In this work, we have evaluated the potential of five PGP bacterial strains as antagonists and biological control agents of ADS-involved Fusarium species. Bacteria belonging to genera Bacillus (Adb14, Hvs2 and FC37), Brevibacterium (Hvs8) and Streptomyces (Hvs6) were selected because of their demonstrated biological control activity against different crop diseases tested earlier [37-40].

In vitro tests, through dual confrontation experiments, clearly showed that $S$. fradiae Hvs6, B. velezensis FC37 and B. paralicheniformis Hvs2 were the most effective strains to inhibit the fungal radial growth of the pathogenic Fusarium isolates, reaching from 73 to $84 \%$ inhibition. Interestingly, Hvs2 and FC37 were the bacterial strains that produced 
the greatest diversity of cell wall degrading enzymes among the five strains tested. The production of cell wall degrading enzymes has been described as a mechanism used by biocontrol agents to control soil-borne pathogens [21,41]. Enzymes such as $\beta$-glucosidase, chitinase, amylase and protease secreted by biocontrol strains of PGPR provoke a direct inhibitory effect on the mycelium growth of fungal pathogens by degrading their cell wall [42].

In planta challenge assays suggested protection against pathogenic isolates of $F$. proliferatum and F. oxysporum f. sp. asparagi by the three bacterial strains. FC37 displayed the best protection effect, which could be related to the higher protease and amylase activities exhibited by this strain. In addition, plants inoculated with the FC37 presented higher root and shoot weights than non-inoculated plants or inoculated with the other two bacteria, suggesting that this strain could also stimulate the asparagus growth. B. velezensis FC37 is the only tested strain able to solubilize phosphorus, suggesting that FC37 could protect the plant by both, limiting the growth of fungi by producing cell wall degrading-enzymes, and enhancing plant growth by converting unavailable forms of phosphorus into forms available for subsequent uptake by the plant. Furthermore, it was found that in addition to some fungal cell wall degrading enzymes [43], B. velezensis strains can produce volatile compounds which can affect the growth of plant pathogenic fungi including Fusarium spp. [44]. It could be possible that strain FC37 produces a volatile compound that it has not been tested in this work. In the same way, the mechanism of action of strain Hvs2 could be related to the production of hydrogen cyanide $(\mathrm{HCN})$, which is a toxic volatile compound that affects the respiratory system of pathogenic fungi resulting in their growth inhibition [45]. However, whether volatile compounds play a role in biocontrol in planta has not yet been confirmed. On the other hand, Hvs2 could effectively control the F. proliferatum isolates and the F. oxysporum Fo14 isolate but not the F. oxysporum Fo125 isolate. The ability of controlling pathogenic Fusarium depends not only on the fungal species (e.g., F. redolens cannot be controlled by any of the assayed bacteria), but within the same species, the factor isolate also influences in the interaction. Just as within a bacterial species some strains work better than others as biocontrol agents, fungal isolates within the same species can be differentially controlled. The genus Fusarium, and especially F. oxysporum, is not easy to control due in part to the high genetic variability of this species $[6,46]$. A combination of these two Bacillus strains should be assessed to determine their synergistic effect on asparagus plant protection.

Hvs6 strain only showed the ability to control F. proliferatum isolates and to a lesser extent than those exhibited by the other two bacteria. This fact contrasts with its in vitro behavior in which Hvs6 produced the greatest percentage of mycelium growth inhibition. It is probable that the environment of the asparagus rhizosphere is not appropriate for the establishment of this strain. The asparagus plants can produce allelopathic compounds [47] that could affect the composition of the rhizosphere and interfere in the establishment of some bacterial species. The high production of siderophore by this strain does not seem to affect the growth of asparagus plants. Siderophores are iron-chelating compounds that play a key role in DNA synthesis and respiratory systems [48]. Some Bacillus species can secrete siderophores under conditions of iron limitation [49]. The use of fertilizer solutions containing iron, such as Hoagland, used to water asparagus plants in growth chamber experiments, could have inhibited the production of siderophores by this strain, although this function could be active in cropping soils lacking this element.

Frequently, strains expressing the best activities in vitro are not always the strains showing the best results in vivo and vice versa [50]. The potential of the bacteria to produce such a compound in vitro does not necessarily correlate with their antagonism in planta. In this way, F. redolens growth could be controlled in vitro but none of the tested bacteria resulted in a good biological control agent for F. redolens isolates in vivo. Even though F. redolens is phylogenetically close to F. oxysporum, there must be essential differences between the species that determine their control by a specific bacterial strain or a type of mechanism. However, since F. proliferatum and F. oxysporum have been proved to be the 
most pathogenic and common Fusarium species involved in asparagus decline syndrome, respectively [6,7], FC37 and Hvs2 could be used as potential biocontrol agents against the main Fusarium species involved in ADS.

\section{Conclusions}

The present work provides for two rhizospheric Bacillus strains (B. velezensis FC37 and B. paralicheniformis Hvs2) which produce cell wall degrading enzymes, antifungal metabolites and plant growth promoter compounds. Their effectiveness has been proved both in vitro and in planta challenge experiments, although their ability to control ADS needs to be further evaluated in field conditions. If these two Bacillus strains were effective in future field trials, they could be used as suitable biocontrol agents for controlling ADS caused by F. proliferatum and F. oxysporum f. sp. asparagi, avoiding or reducing the use of chemical fumigants.

Supplementary Materials: The following are available online at https:/ /www.mdpi.com/article/10 .3390/app11188356/s1.

Author Contributions: Conceptualization, N.C. and M.C.; Methodology, M.C. and E.D.l.L.; Validation, E.D.1.L.; Formal Analysis, E.D.1.L.; Investigation, N.C., M.C. and E.D.l.L.; Resources, N.C.; Writing-Original Draft Preparation, N.C.; Writing-Review and Editing, N.C. and M.C. Supervision, N.C. and M.C.; Funding Acquisition, N.C. All authors have read and agreed to the published version of the manuscript.

Funding: This work was funded by the "Operational Program Smart Growth" from the National Institute for Agricultural and Food Research and Technology (INIA) and European Regional Development Fund (ERDF) 2014-2020 (RTA2015-00008-C02-01) and by the Andalusian Institute of Agricultural and Fisheries Research and Training (IFAPA) and European Regional Development Fund: PP.TRA.2019.017. Eduardo De la Lastra was supported by a PhD fellowship from the European Union and INIA.

Institutional Review Board Statement: Not applicable.

Informed Consent Statement: Not applicable.

Data Availability Statement: The data presented in this study are available on request from the corresponding author.

Conflicts of Interest: The authors declare no conflict of interest. The funders had no role in the design of the study; in the collection, analyses, or interpretation of data; in the writing of the manuscript, or in the decision to publish the results.

\section{References}

1. Rodríguez, R.; Jaramillo, S.; Rodríguez, G.; Espejo, J.A.; Guillén, R.; Fernández-Bolaños, J.; Heredia, A.; Jiménez, A. Antioxidant activity of ethanolic extracts from several asparagus cultivars. J. Agric. Food Chem. 2005, 53, 5212-5217. [CrossRef] [PubMed]

2. Lee, J.W.; Lee, J.H.; Yu, I.H.; Gorinstein, S.; Bae, J.H.; Ku, Y.G. Bioactive compounds, antioxidant and binding activities and spear yield of Asparagus officinalis L. Plant Foods Hum. Nutr. 2014, 9, 175-181. [CrossRef] [PubMed]

3. Elmer, W.H. Fusarium diseases of asparagus. In Fusarium: Paul E. Nelson Memorial Symposium; Summerell, B.A., Leslie, J.F., Backhouse, D., Bryden, W.L., Burgess, L.W., Eds.; American Phytopathological Society Press: St. Paul, MN, USA, 2001; pp. 248-262.

4. Blok, W.J.; Bollen, G.J. The role of autotoxins from root residues of the previous crop in the replant disease of asparagus. Neth. J. Plant Pathol. 1993, 99, 29-40. [CrossRef]

5. Elmer, W. Asparagus decline and replant problem: A look back and a look forward at strategies for mitigating losses. Acta Hortic. 2018, 1223, 195-204. [CrossRef]

6. Brizuela, A.M.; De la Lastra, E.; Marín-Guirao, J.I.; Gálvez, L.; de Cara-García, M.; Capote, N.; Palmero, D. Fusarium consortium populations associated with asparagus crop in Spain and their role on field decline syndrome. J. Fungi 2020, 6, 336. [CrossRef]

7. De la Lastra, E.; Marín-Guirao, J.I.; López-Moreno, F.J.; De Cara, M.; Soriano, T.; Capote, N. Especies de Fusarium relacionadas con el síndrome del decaimiento del espárrago en Andalucía. Phytoma 2020, 324, 2 -9.

8. Corpas-Hervias, C.; Melero-Vara, J.M.; Molinero-Ruiz, M.L.; Zurera-Muñoz, C.; Basallote-Ureba, M.J. Characterization of isolates of Fusarium spp. obtained from asparagus in Spain. Plant Dis. 2006, 90, 1441-1451. [CrossRef] 
9. De la Lastra, E.; Marín-Guirao, J.I.; López-Moreno, F.J.; Soriano, T.; de Cara-García, M.; Capote, N. Potential inoculum sources of Fusarium species involved in asparagus decline syndrome and evaluation of soil disinfestation methods by qPCR protocols. Pest Manag. Sci. 2021, in press. [CrossRef]

10. Liu, J.; Matsubara, Y. Induced systemic resistance to Fusarium root rot and changes in antioxidative ability by arbuscular mycorrhizal fungus and non-pathogenic Fusarium oxysporum in Asparagus Plants. J. Jpn. Soc. Agric. Technol. Manag. 2016, 23, 21-29. [CrossRef]

11. Elmer, W.H. Combining nonpathogenic strains of Fusarium oxysporum with sodium chloride to suppress Fusarium crown rot of asparagus in replanted fields. Plant Pathol. 2004, 53, 751-758. [CrossRef]

12. Haque, S.I.; Matsubara, Y. Arbuscular-mycorrhiza-induced salt tolerance and resistance to Fusarium root rot in asparagus plants. Acta Hortic. 2018, 1227, 365-372. [CrossRef]

13. Arriola, L.; Hausbeck, M.; Rogers, J.; Safir, G. The effect of Trichoderma harzianum and arbuscular mycorrhizae on Fusarium root rot in asparagus. HortTechnology 2000, 10, 141-144. [CrossRef]

14. Surono; Narisawa, K. The inhibitory role of dark septate endophytic fungus Phialocephala fortinii against Fusarium disease on the Asparagus officinalis growth in organic source conditions. Biol. Control 2018, 121, 159-167. [CrossRef]

15. Rubio-Pérez, E.; Molinero-Ruiz, M.L.; Melero-Vara, J.M.; Basallote-Ureba, M.J. Selection of potential antagonists against asparagus crown and root rot caused by Fusarium spp. Commun. Agric. Appl. Biol. Sci. 2008, 73, 203-206. Available online: https: //pubmed.ncbi.nlm.nih.gov/19226757/ (accessed on 31 August 2021).

16. Smith, J.; Putnam, A.; Nair, M. In vitro control of Fusarium diseases of Asparagus-officinalis L. with a Streptomyces or its polyene antibiotic, faeriefungin. J. Agric. Food Chem. 1990, 38, 1729-1733. [CrossRef]

17. Elmer, W.H. Association between $\mathrm{Mn}$-reducing root bacteria and $\mathrm{NaCl}$ applications in suppression of Fusarium crown and root rot of asparagus. Phytopathology 1995, 85, 1461-1467. [CrossRef]

18. Godfrey, S.A.C.; Silby, M.W.; Falloon, P.G.; Mahanty, H.K. Biological control of Phytophthora megasperma var. sojae, causal agent of Phytophthora rot of asparagus, by Pseudomonas aureofaciens PA147-2: A preliminary field trial. N. Z. J. Crop Hortic. Sci. 2000, 28, 97-103. [CrossRef]

19. Khan, N.; Martínez-Hidalgo, P.; Ice, T.A.; Maymon, M.; Humm, E.A.; Nejat, N.; Sanders, E.R.; Kaplan, D.; Hirsch, A.M. Antifungal activity of Bacillus species against Fusarium and analysis of the potential mechanisms used in biocontrol. Front. Microbiol. 2018, 9, 2363. [CrossRef]

20. Kashyap, B.K.; Solanki, M.K.; Pandey, A.K.; Prabha, S.; Kumar, P.; Kumari, B. Bacillus as Plant Growth Promoting Rhizobacteria (PGPR): A promising green agriculture technology. In Plant Health Under Biotic Stress; Ansari, R., Mahmood, I., Eds.; Springer: Singapore, 2019. [CrossRef]

21. Goswami, D.; Thakker, J.N.; Dhandhukia, P.C. Portraying mechanics of plant growth promoting rhizobacteria (PGPR): A review. Cogent Food Agric. 2016, 2, 1127500. [CrossRef]

22. Liu, K.; McInroy, J.A.; Hu, C.H.; Kloepper, J.W. Mixtures of plant-growth-promoting rhizobacteria enhance biological control of multiple plant diseases and plant-growth promotion in the presence of pathogens. Plant Dis. 2018, 102, 67-72. [CrossRef]

23. Hoagland, D.; Arnon, D.I. The Water-Culture Method for Growing Plants without Soil, 2nd ed.; Circular 347; University of California Agricultural Experiment Station: Berkeley, CA, USA, 1950; p. 32.

24. Leslie, J.F.; Summerell, B.A. The Fusarium Laboratory Manual; Blackwell: Ames, IA, USA, 2006; p. 388.

25. Nelson, P.E.; Tousson, T.A.; Marasas, W.F.O. Fusarium Species: An Illustrated Manual for Identification; The Pennsylvania State University Press: University Park, PA, USA, 1983.

26. Mesa, J.; Mateos-Naranjo, E.; Caviedes, M.A.; Redondo-Gómez, S.; Pajuelo, E.; Rodríguez-Llorente, I.D. Endophytic cultivable bacteria of the metal bioaccumulator Spartina maritima improve plant growth but not metal uptake in polluted marshes soils. Front. Microbiol. 2015, 6, 1450. [CrossRef]

27. Gong, X.; Gruninger, R.J.; Qi, M.; Paterson, L.; Forster, R.J.; Teather, R.M.; Mcallister, T.A. Cloning and identification of novel hydrolase genes from a dairy cow rumen metagenomic library and characterization of a cellulase gene. BMC Res. Notes 2012, 5, 566. [CrossRef]

28. Bano, N.; Musarrat, J. Characterization of a new Pseudomonas aeruginosa strain NJ-15 as a potential biocontrol agent. Curr. Microbiol. 2003, 46, 324-328. [CrossRef]

29. Pacheco-Hernández, X.J.; Rodríguez-Dorantes, A.; González-Rivera, R.; Amora-Lazcano, E.; Guerrero-Zúñiga, L.A.; RodríguezTovar, A.V. Evaluación del efecto fitotóxico de rizobacterias deletéreas sobre el crecimiento radical de Axonopus affinis (Chase) y Lens esculenta (Moench). Polibotánica 2015, 40, 137-152. [CrossRef]

30. Reetha, A.K.; Pavani, S.L.; Mohan, S. Hydrogen cyanide production ability by bacterial antagonist and their antibiotics inhibition potential on Macrophomina phaseolina (Tassi.) Goid. Int. J. Curr. Microbiol. Appl. Sci. 2014, 3, 172-178.

31. Benizri, E.; Courtade, A.; Picard, C.; Guckert, A. Role of maize root exudates in the production of auxins by Pseudomonas fluorescens M.3.1. Soil Biol. Biochem. 1998, 30, 1481-1484. [CrossRef]

32. Alexander, D.B.; Zuberer, D.A. Use of chrome azurol S reagents to evaluate siderophore production by rhizosphere bacteria. Biol. Fertil. Soils 1991, 12, 39-45. [CrossRef]

33. De Freitas, J.R.; Banerjee, M.R.; Germida, J.J. Phosphate-solubilizing rhizobacteria enhance the growth and yield but not phosphorous uptake of canola (Brassica napus L.). Biol. Fertil. Soils 1997, 24, 358-364. [CrossRef] 
34. Pastrana, A.; Basallote-Ureba, M.; Aguado, A.; Akdi, K.; Capote, N. Biological control of strawberry soil-borne pathogens Macrophomina phaseolina and Fusarium solani, using Trichoderma asperellum and Bacillus spp. Phytopathol. Mediterr. 2016, 55, 109-120. [CrossRef]

35. Abdel-Gayed, M.A.; Abo-Zaid, G.A.; Matar, S.M.; Hafez, E.E. Fermentation, formulation and evaluation of PGPR Bacillus subtilis isolate as a bioagent for reducing occurrence of peanut soil-borne diseases. J. Integr. Agric. 2019, 18, 2080-2092. [CrossRef]

36. Viejobueno, J.; Albornoz, P.L.; Camacho, M.; de los Santos, B.; Martínez-Zamora, M.G.; Salazar, S.M. Protection of strawberry plants against Charcoal rot disease (Macrophomina phaseolina) induced by Azospirillum brasilense. Agronomy 2021, 11, 195. [CrossRef]

37. Bubici, G. Streptomyces spp. as biocontrol agents against Fusarium species. CAB Rev. 2018, 13, 50. [CrossRef]

38. Abed, H.; Rouag, N.; Mouatassem, D.; Rouabhi, A. Screening for Pseudomonas and Bacillus antagonistic rhizobacteria strains for the biocontrol of Fusarium wilt of chickpea. Eurasian J. Soil Sci. 2016, 5, 182-191. [CrossRef]

39. Camacho, M.; Aparicio, L.; Perez-Carmona, C.; de los Santos, B. Empleo de bacterias rizosféricas como sustitutas de productos químicos de síntesis para un cultivo sostenible de la fresa (Fragaria x ananassa Duch.). Actas Hortic. (Febrero) 2017, 459-466, ISBN 978-84-697-6628-6.

40. Wang, C.; Zhao, D.; Qi, G.; Mao, Z.; Hu, X.; Du, B.; Liu, K.; Ding, Y. Effects of Bacillus velezensis FKM10 for promoting the growth of Malus hupehensis Rehd. and inhibiting Fusarium verticillioides. Front. Microbiol. 2020, 10, 2889. [CrossRef]

41. Beneduzi, A.; Ambrosini, A.; Passaglia, L.M. Plant growth-promoting rhizobacteria (PGPR): Their potential as antagonists and biocontrol agents. Genet. Mol. Biol. 2012, 35, 1044-1051. [CrossRef] [PubMed]

42. Blake, C.; Christensen, M.N.; Kovács, Á.T. Molecular aspects of plant growth promotion and protection by Bacillus subtilis. Mol. Plant-Microbe Interact. 2021, 34, 15-25. [CrossRef]

43. Gorai, P.S.; Ghosh, R.; Konra, S.; Mandal, N.C. Biological control of early blight disease of potato caused by Alternaria alternata EBP3 by an endophytic bacterial strain Bacillus velezensis SEB1. Biol. Control 2021, 156, 104551. [CrossRef]

44. Myo, E.M.; Liu, B.; Ma, J.; Shi, L.; Jiang, M.; Zhang, K.; Ge, B. Evaluation of Bacillus velezensis NKG-2 for bio-control activities against fungal diseases and potential plant growth promotion. Biol. Control 2019, 134, 23-31. [CrossRef]

45. Kirimura, K.; Hirowatari, Y.; Usami, S. Alterations of respiratory systems in Aspergillus niger under the conditions of citric acid fermentation. Agric. Biol. Chem. 1987, 51, 1299-1303. [CrossRef]

46. O'Donnell, K.; Gueidan, C.; Sink, S.; Johnston, P.R.; Crous, P.W.; Glenn, A.; Riley, R.; Zitomer, N.C.; Colyer, P.; Waalwijk, C.; et al. A two-locus DNA sequence database for typing plant and human pathogens within the Fusarium oxysporum species complex. Fungal Genet. Biol. 2009, 46, 936-948. [CrossRef]

47. Noperi-Mosqueda, L.C.; López-Moreno, F.J.; Navarro-León, E.; Sánchez, E.; Blasco, B.; Moreno, D.A.; Soriano, T.; Ruiz, J.M. Effects of asparagus decline on nutrients and phenolic compounds, spear quality, and allelopathy. Sci. Hortic. 2020, 261, 109029. [CrossRef]

48. Ellermann, M.; Arthur, J.C. Siderophore-mediated iron acquisition and modulation of host-bacterial interactions. Free Radic. Biol. Med. 2017, 105, 68-78. [CrossRef] [PubMed]

49. Williams, K.M.; Martin, W.E.; Smith, J.; Williams, B.S.; Garner, B.L. Production of protocatechuic acid in Bacillus thuringiensis ATCC33679. Int. J. Mol. Sci. 2012, 13, 3765. [CrossRef]

50. Besset-Manzoni, Y.; Joly, P.; Brutel, A.; Gerin, F.; Soudière, O.; Langin, T.; Prigent-Combaret, C. Does in vitro selection of biocontrol agents guarantee success in planta? A study case of wheat protection against Fusarium seedling blight by soil bacteria. PLoS ONE 2019, 14, e0225655. [CrossRef] [PubMed] 